\title{
PEMBUATAN BIOPLASTIK DARI KITOSAN DAN SORBITOL DENGAN PENAMBAHAN MINYAK ATSIRI SERAI
}

\author{
Kharisma Putri Nanda1 ${ }^{1}$, Zidni Azizati ${ }^{2}$ \\ ${ }^{1}$ Program Sarjana Jurusan Kimia Fakultas Sains dan Teknologi UIN Walisongo Semarang \\ 2Jurusan Kimia Fakultas Sains dan Teknologi UIN Walisongo Semarang \\ Email: kharismaputrinanda@gmail.com
}

\begin{abstract}
Abstrak
Plastik merupakan bahan yang banyak digunakan dalam kehidupan, namun plastik juga menjadi permasalahan skala global yakni sampah plastik karena plastik yang bersal dari bahan baku minyak bumi sulit untuk diuraikan. Sehingga dibutuhkan plastik yang ramah lingkungan (bioplastik). Dalam penelitian ini dilakukan pembuatan bioplastik dari kitosan dan sobitol sebagai pemplastis serta minyak atsiri serai sebagai insektisida nabati. Tujuan dari penelitian ini adalah untuk mempelajari sifat mekanik bioplastik. Bioplastik yang dihasilkan dilakukan mengujian mekanik kuat tarik (tensile strenght) dan perpanjangan (elongasi).Hasil penelitian menunjukkan penambahan $1 \mathrm{~mL}$ minyak atsiri serai berpengaruh terhadap sifat mekanik bioplastik dengan nilai kuat tarik dan elongasi bioplastik eksperimen masing-masing sebesar 3.50 Mpa dan 7.54\% dari nilai biplastik kontrol masing-masing sebesar 1.427 Mpa dan 3.97\%.
\end{abstract}

Kata kunci : Bioplastik; Kitosan; Sorbitol; Minyak Atsiri Sereh

\section{Pendahuluan}

Plastik merupakan bahan yang banyak dipakai dalam kehidupan sehari-hari, diantaranya sebagai pembungkus makanan, kantong belanjaan, keperluan kantor, dan berbagai sektor lainnya. Hal ini dikarenakan plastik memiliki sifat fleksibel, kuat, ringan, dan stabil. Kebutuhan plastik yang sangat besar menyebabkan permasalahan skala global yaitu sampah plastik. Sampah plastik yang terbuat dari bahan baku minyak bumi sulit untuk diuraikan oleh mikroorganisme di dalam tanah. Oleh karena itu perlu dilakukan upaya untuk menanggulangi permasalahan lingkungan tersebut, salah satunya adalah mengembangkan bahan plastik ramah lingkungan (bioplastik).

Bioplastik merupakan plastik yang dapat diuraikan kembali oleh mikroorganisme secara alami menjadi senyawa yang ramah lingkungan. Bahan alam yang telah banyak dimanfaatkan sebagai penyusun bioplastik salah satunya adalah kitosan (Katili dkk., 2013). Aplikasi kitosan sebagai pengganti plastik sintetik telah banyak dilakukan penelitian (Muhammad Ali Rohman, 2016)(M. Hasan, 2012). Kitosan adalah senyawa golongan karbohidrat yang dapat dihasilkan dari libah hasil 78

Copyright (C) 2018 WJC | ISSN 2621-5985 (online) | ISSN 2549-385X (print)

Volume 1, Nomor 2, 2018 
laut (Harini dkk., 2004). Bioplastik yang dihasilkan dari kitosan memiliki kekuatan tarik yang cukup tinggi namun memiliki tekstur yang kaku (Khiar,. dkk, 2006) sehingga diperlukan penambahan bahan pemplastis (plasticizer).

Berbagai penelitian tentang penambahan pemplastis telah dilakukan. Penambahan pemplastis dapat menurunkan kekakuan dan meningkatkan sifat mekanik bioplastik. (M. Hasan, 2012). Beberapa jenis pemplastis yang sering digunakan adalah sorbitol (Yuli Dani dkk, 2010), Gliserol (Pamilia, dkk, 2014) (Prima A. H., dkk, 2015), Refined Bleached and Deodorized Palm Oil / REDPO (M. Hasan, 2012), Castor Oil (M. Hasan dkk, 2017).

Salah satu peggunaan plastik adalah sebagai pembungkus bahan makanan. Beras merupakan bahan baku makanan pokok sebagian besar masyarakat Indonesia. Beras yang disimpan dalam gudang seringkali mengalami kerusakan akibat hama. Serangga $S$. oryzae merupakan salah satu hama yang menyerang beras (Dwi Fajarwati, 2015). Senyawa sitronellol dalam minyak atsiri serai dapat digunakan sebagai insect repellent terhadap anthropoda termasuk S. oryzae (Soegiarti, 1983).

Belum ada publikasi yang melaporkan tentang pengaruh penambahan minyak atsiri serai terhadap sifat mekanik bioplastik. Oleh karen itu dalam penelitian ini akan dilakukan pembuatan biopastik dari kitosan dan pemplastis sorbitol serta dengan penambahan minyak atsiri serai untuk meningkatka fungsi bioplastik yakni sebagai anti serangga.

\section{Metode Penelitian}

Tempat dan Waktu Penelitian

Penelitian dilakukan di Laboratorium Kimia, Fakultas Sains dan Teknologi, Universitas Islam Negeri Walisongo Semarang. Penelitian dilakukan pada bulan Mei 2018.
Alat dan Bahan

Alat yang digunakan dalam penelitian ini adalah, baker glass $250 \mathrm{~mL}$, pipet tetes, spatula, pengaduk, gelas ukur $100 \mathrm{~mL}$, termometer, cawan petri, labu ukur $100 \mathrm{~mL}$, pipet volume $100 \mathrm{~mL}$, gelas ukur $10 \mathrm{~mL}$, magnetik stirer. Bahan yang digunakan dalam penelitian ini adalah kitosan, sorbitol, aquades, asam asetat $1 \%$, minyak atsiri serai.

Pembuatan Pelarut

Langkah pertama yang dilakukan adalah pengenceran $1 \mathrm{~mL}$ asam asetat $100 \%$ menjadi $100 \mathrm{~mL}$ asam asetat $1 \%$.

Pembuatan Bioplastik

Pembuatan bioplastik kontrol. Selanjutnya menimbang kitosan seberat 1,5 gram dengan menggunakan neraca analitik. Kitosan yang telah ditimbang lalu dilarutkan kedalam $40 \mathrm{~mL}$ asam asetat $1 \%$ dan diaduk dengan menggunakan magnetik stirer pada suhu $60^{\circ} \mathrm{C}$ selama 60 menit. Kemudian sorbitol dimasukkan dalam campuran sebanyak $1 \mathrm{~mL}$ dan diaduk dengan magnetic stirer selama 15 menit dengan suhu $60^{\circ} \mathrm{C}$. ditunggu hingga homogen.

Pembuatan bioplastik eksperimen. kitosan sebanyak 1,5 gram yang telah ditimbang dilarutkan dalam $40 \mathrm{~mL}$ asam asetat 1\%. Diaduk dengan menggunakan magnetic stirer dalam suhu $60^{\circ} \mathrm{C}$ selama 60 menit. Kemudian sorbitol dimasukkan dalam campuran sebanyak $1 \mathrm{~mL}$ dan diaduk dengan magnetic stirer selama 15 menit dengan suhu $60^{\circ} \mathrm{C}$. Ditunggu hingga homogen. Kemudian ditambah dengan minyak atsiri serai sebanyak $1 \mathrm{~mL}$. diaduk hingga homogen.

Kedua sampel kemudian dicetak dalam cetakan aluminium foil dan di oven selama 3 jam dengan suhu $60^{\circ} \mathrm{C}$. Bioplastik yang dihasilkan diuji karakteristik sifat mekanik kekuatan tarik (tesile strengt) dan perpanjangan (elongation). 
Uji Pegaruh Bioplastik Terhadap Kutu Beras

Sebanyak 10 ekor kutu beras dimasukkan kedalam kotak yang berisi 40 gram beras. Pengamatan dilakukan pada 1 jam pertama, 3 jam, 6 jam dan 9 jam setelah di sebarkan kutu beras. Diamati perubahan yang terjadi pada kutu beras.

\section{Hasil dan Pembahasan}

Bioplastik yang telah diperoleh dilakukan uji karakteristik sifat mekanik. Pengujian mekanik yang dilakukan adalah kekuatan tarik (tensile strenght) dan elongasi.

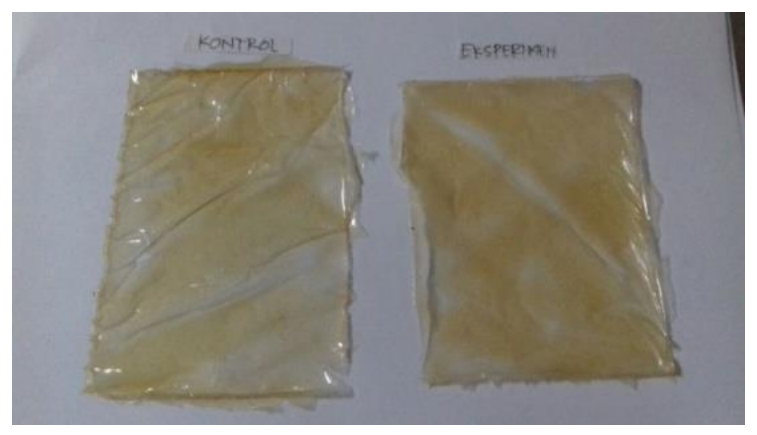

Gambar 1. Bioplastik kitosan dan sorbitol (a bioplastik kontrol), Bioplastik kitosan, sorbitol dan minyak atsiri serai(b bioplastik ekserimen)

Penampakan fisik bioplastik tanpa penambahan minyak atsiri serai memiliki warna yang lebih jernih dibandingkan dengan bioplastik dengan penambahan minyak atsiri serai yang memilii warna lebih pekat.

\begin{tabular}{|l|c|c|}
\hline Sampel & $\begin{array}{r}\text { Kuat } \\
\text { Tarik } \\
\text { (Mpa) }\end{array}$ & $\begin{array}{c}\text { Pemanjangan } \\
(\%)\end{array}$ \\
\hline Kontrol & 1.427 & 3.97 \\
\hline Eksperimen & 3.502 & 7.54 \\
\hline
\end{tabular}

Tabel 1. Hasil uji karakteristik sifat mekanik bioplastik
Kuat tarik adalah besar gaya yang diperlukan hingga bioplastik putus. rendahnya nilai kuat tarik suatu bioplastik maka menunjukkan bioplastik tersebut mudah rusak dan nilai kuat tarik yang tinggi mengindikasikan bahwa bioplastik dapat melindungi produk dari ganggguan mekanik berupa gesekan maupun benturan terhadap produk.

Menurut Isnawati (2008), apabila persen pemanjangan (Percent elongation) tinggi maka mengindikasikan bioplastik yang dihasilkan tidak mudah putus karena mampu menahan beban dan gaya tarik yang diberikan.

Penambahan minyak atsiri serai yang ditujukan sebagai bahan anti serangga ternyata memberikan pengaruh yang signifikan terhadap sifat mekanik bioplastik. Dimana dengan penambahan minyak atsiri serai sebanyak $1 \mathrm{~mL}$ menghasilkan nilai kuat tarik dan persen regangan yang lebih besar dibandingkan bioplastik kontrol. Berdasarkan hasil nilai uji mekanik diketahui bahwa minyak atsiri serai dapat bertindak sebagai pemplastis. Pemplastis akan menurukan kekakuan rantai polimer kitosan yang mempermudah rantai biopolimer berotasi sehingga kelenturannya meningkat.

Pada pengujian pengaruh bioplastik terhadap kutu beras belum menunjukan suatu perubahan. Hal ini dikarenakan konsentrasi minyak atsiri serai yang digunakan kurang tinggi sehingga tidak menimbulkan efek terhadap kutu beras.

\section{Kesimpulan}

Berdasarkan hasil penelitian menunjukkan bahwa penambahan $1 \mathrm{~mL}$ minyak atsiri pada bioplasstik kitosan dan sorbitol berpengaruh terhadap sifat mekanik bioplastik dengan nilai kuat tarik dan elongasi bioplastik sampel masingmasing sebesar 3.502 Mpa dan 7.54\% dari nilai 
biplastik kontrol masing-masing sebesar 1.427 Mpa dan 3.97\%.

\section{Daftar Pustaka}

Coniwati, Pamilia, L. Laila, dan M. R. Alfira. 2014. Pembuatan Film Plastik Biodegradabel dari Pati Jagung dengan Penambahan Kitosan dan Pemplastis Gliserol. Jurnal Teknik Kimia, 20 (4)

Darni, Yuli dan Herti Utami. 2010. Studi Pembuatan dan Karakteristik Sifat Mekanik dan Hidrofobisitas Bioplastik dari Pati Sorgum. Jurnal Rekayasa Kimia dan Lingkungan, 7 (4) : 88-93.

Fajarwati, Dewi,. dkk. 2015. Uji repelensi dari ekstrak daun jeruk purut (Cytrus hystrix) terhadap hama beras Sitophilus oryae Linnaeus (Coleptera curculionidae). Jurnal Hama dan Penyakit Tumbuhan. 3 (1): 23384336.

Harini, N., S. Winarni dan E. Setyaningsih. 2004. Pemanfaatan Teknologi Pengolahan Limbah Kulit / Kepala Udang Menjadi Chotosan untuk Ingredient Pembuatan Permen di Home Industri Kebon Agung Kepanjen Malang. Fakultas Pertanian. Universitas Muhammadiiyah Malang. Malang. Jurnal Dedikasi, 1 (2).

Hasan, M. 2012. Pembuatan Termoplastik Ramah Lingkungan Berbasis Khitosan melalui Penambahan Refined bleached and Deodorized Palm Oil (REDPO) dan Glileserol sebagai Pemplastis. Jurnal Ilmiah Pendidikan Biologi, Biologi Edukasi, 4 (2) : 100-103

Hasan, M., R. F. I. Rahmayani dan Munandar. 2017. Bioplastic from Chitosan and Yellow Pumpkinn Starch Castor Oil as Plasticizer.
International Conferance on Advanced Materials for Better Future

Isnawati, R. 2008. Kerajinan Rasio Mentega dan Chitosan dalam Edible Film Protein Pollard terhadap Sifat Fisik Telur Ayam. Skripsi. Fakultas Peternakan Universitas Brawijaya. Malang.

Katili, S., B. T. Harsunu dan S. Irawan. 2013. Pengaruh Konsentrasi Plasticizer Gliserol dan Komposisi Kitosan dalam Zat Pelarut Terhadap Sifat Fisik Edible Film dari Khitosan. Jurnal Teknologi, 6 (1) : 29-38

Khiar. A. S. A., Puteh, R., Arof, A. K. (2006).Conductivity studies of a Chitosanbased Polymer Electrolite. Physica B, 373 : 23-37

Prima A., H., dan H., Wijayanti. 2015. Pembuatan Film Bioplastik Biodegradable dari Limbah Biji Durian (Durio Zibethinus Murr. Jurnal Bahan Alam Terbarukan, 4 (1): 21-26.

Rohman, M. A. 2016. Pengaruh Penambahan Gliserol Terhadap Karakteristik Film Bioplastik Kitosan Terplastis Carboxy Methil Celulose (CMC). Skripsi. Fakultas Perikanan dan Kelautan. Universitas Airlangga. Surabaya.

Soegiarti, M. 1983. Menghindari Kutu Beras. Sarinah 26 Desember: Jakarta. 